\title{
10
}

\section{Out-Migration from Peripheries: How Cumulated Individual Strategies Affect Local Development Capacities}

\author{
Aura Moldovan
}

\section{Introduction}

Over the past two and a half decades, the EU member states from Central and Eastern Europe (CEE) have transitioned from state socialism to democracy, from a centralised to a market economy. At the national level, the post-socialist transition has brought economic growth to these countries. At a regional scale however, socio-economic inequalities have developed and the gap between centres and peripheries has increased (Kurkó 2010; PoSCoPP Research Group 2015; Leibert 2015). Over the years, capital cities and regional urban centres have transitioned more successfully and have found ways to integrate themselves into global production networks. As a result of higher capital investment compared to the rest of the region, these urban centres accumulate benefits in terms of job creation, higher tax revenues, more public investments in infrastructure, and higher levels of engagement

\footnotetext{
A. Moldovan $(\bowtie)$

Faculty of Geography, Babeş-Bolyai-University, Cluj-Napoca, Romania

(C) The Author(s) 2019

T. Lang and F. Görmar (eds.), Regional and Local Development

in Times of Polarisation, New Geographies of Europe,

https://doi.org/10.1007/978-981-13-1190-1_10
} 
in a variety of political and innovation networks (Gottdiener and Budd 2005). The peripheries however have not coped as well. More secluded rural areas, mining settlements and the former mono-structural industrial regions are facing a much slower development or even decline. Left with limited access to desirable resources (material or symbolic), and with restricted room for autonomous action (Kreckel 2004), they are experiencing increasing marginalisation and peripheralisation (Pütz 1999; Surd et al. 2011; Török 2014; Benedek 2015).

With accession to the European Union, CEE countries were incentivised to adopt neoliberal competitiveness-centred policies. And despite the European Union's plea for balanced, integrated and inclusive development, its policies have favoured the increasing development of existing urban centres (Lang 2011; Fischer-Tahir and Naumann 2013). Thus, investment flows generated by advanced local and regional economic agents were mainly concentrated in urban centres and their metropolitan areas, and did not trickle down to peripheries, as traditional models of economic growth would suggest (Spoor 2013; Benedek and Moldovan 2015). In this context, it is particularly the rural areas of the post-socialist countries that have experienced increasing peripheralisation (Fischer-Tahir and Naumann 2013). This is not to say that rurality constitutes a periphery per se. On the contrary, through suburbanisation or by successfully marketing images of a rural idyll, some villages have seen intensive socio-economic development. Their share, however, is rather small, as specific conditions have to be met in terms of accessibility, the state of physical and service infrastructure, and attractiveness of tourist destinations (Keim 2006). More often, rural areas are struggling with economic and demographic issues brought on by market-driven devaluation of local assets (cheap labour, agricultural land, local skills and relations) (Nagy et al. 2015), and by fierce competition with international distributors of products once sourced from regional or national rural areas (such as food, lumber, yarn or leather) (Keim 2006). As a result, rural peripheries in CEE are among the poorest regions in the European Union (Leibert 2013).

Taking one such post-socialist rural periphery as a case study, this chapter relies on structured interviews collected in July 2017 in villages of Sălaj County in Romania (Map 1). Sălaj is mostly rural (93\% of 


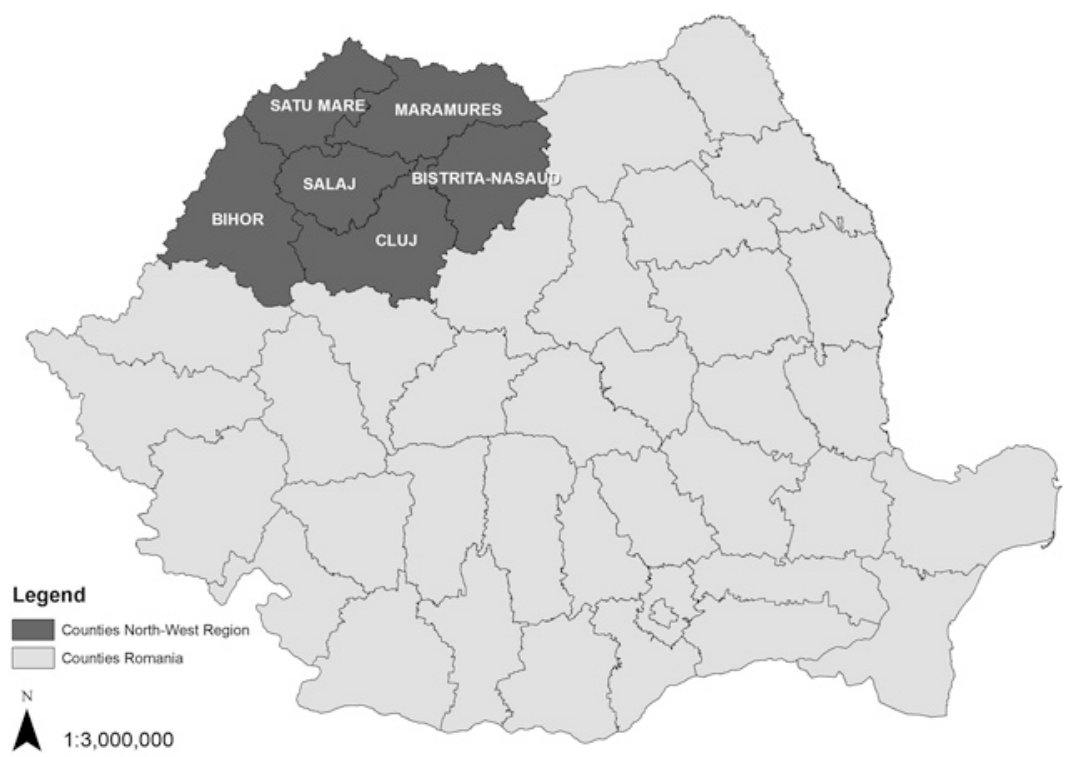

Map 1 Geographic location of the North-West Region and of Sălaj County in Romania. Source Prepared by the author

its settlements are villages and $61 \%$ of the population lives in villages, according to 2011 census data), without having (yet) developed a strong functional urban area around any of its four cities. This means that the county is mostly comprised of structurally disadvantaged villages. It is also the least developed county in terms of human, health, vital and material capital (Ionescu-Heroiu et al. 2013, 240) in one of the most polarised NUTS2 regions in Romania, the North-West Region. Here, the city of Cluj-Napoca, which is one of the main economic engines in the entire country, acts as the regional centre, while the North-West Region as a whole remains one of Romania's "lagging regions", with a GDP per capita (PPS) below 50\% of the EU average (Cristea et al. 2017, 7). As the villages in Sălaj are peripheral across various spatial scales, the case study area allows an in-depth analysis of the effects of increasing regional polarisation and peripheralisation.

Using this case study as a representation of post-socialist rural peripheries, the chapter aims to critically engage with the economic and 
demographic struggles that such peripheries are facing, specifically in relation to one of the main contributors to peripheralisation, selective out-migration (Kühn and Weck 2013; Kühn 2015; Leibert 2015). While previous studies on the topic have focused heavily on the structural factors that affect socio-spatial polarisation and peripheralisation, this chapter addresses a gap in the research by employing an actorbased approach (Fischer-Tahir and Naumann 2013; PoSCoPP Research Group 2015; Miggelbrink and Meyer 2015) (as further elaborated in Chapter 2). The selected empirics first illustrate how actors affected by peripheralisation utilise different forms of out-migration as strategies to improve their quality of life (in Sect. 3.1). The empirical findings secondly showcase the impact the cumulative mobility of these actors has on shaping local development potentials and strategies, as described by local public officials (in Sect. 3.2). Overall the analysis contributes to the debate on how local development is affected in times of polarisation, by revealing how the interdependency between peripheralisation and out-migration limits the decision-making capacity of local administrative leaders, and diminishes local development capacities in peripheral settlements even further (in Chapter 4).

\section{Peripheralisation and Selective Out- Migration: A Deepening Vicious Circle}

Recent studies examining the increasing regional polarisation in Central and Eastern Europe have focused on a more process-based and dynamic understanding of the terms "polarisation", "centralisation" and "peripheralisation". At the core of this conceptualisation lies the relation between the two interdependent types of spaces — centres (or cores) and peripheriesboth of which are continuously being re-created in relation to each other across various scales, and cannot define themselves as one or the other without referencing their counterpart (Keim 2006; Warf 2008; Bernt and Liebmann 2013; Kühn 2015; PoSCoPP Research Group 2015). Thus, peripheralisation can be described as a process in which peripheries experience a gradual and persisting decline in socio-spatial development, as well as a long-lasting solidification of structural deficits in relation to 
a dominant centre, which widens the disparities between them (Keim 2006). Such peripheries are faced with relatively low income, a low level of education, low quality occupation (e.g. subsistence agriculture or lowskilled jobs) (following Kreckel 2004), demographic shrinkage, ageing, and the out-migration of young, highly-educated people (following Kühn 2015). These deficits translate into institutional thinness and a limited capacity of the peripheral space to secure a high quality of life for its population, and implicitly cause a growing dependence on the centre (Keim 2006; PoSCoPP Research Group 2015).

As a process, selective emigration is one of the main contributors to increasing peripheralisation, along with decoupling, dependency and stigmatisation (Kühn and Weck 2013,40). On the one hand, the existence of strong emigration flows among young and skilled adults can be seen as a consequence of peripheralisation, as it indicates an existing lack of educational facilities, reduced availability for highly skilled employment, as well as an existing stigma regarding future perspectives (Bernt and Liebmann 2013; Leibert 2015). But at the same time, this brain drain (and the implicit demographic shrinkage that it accompanies) is also a cause for further peripheralisation. Not only does the decreasing share of the active population reduce the amount of local taxes and incomes, thus diminishing the ability of the local municipality to maintain or modernise social and physical infrastructures, but also the emigration of skilled professionals reduces the local capacity for innovation (Bernt and Liebmann 2013). Overall, out-migration and shrinkage negatively influence the level of sustainability for existing local economies, the prospects of new economic projects, as well as the overall quality of life. Ultimately, this encourages future waves of out-migration and leads to a vicious circle that reproduces peripherality (Massey 1990).

While much of the existing literature investigates spatial disparities and the interdependence between out-migration and peripheralisation in terms of the participating structural processes, recent scholarship is also arguing for complementing this socio-structural focus with a more actor-based approach, noting the existing gaps in research regarding both the actors causing peripheralisation and the actors affected by it (Fischer-Tahir and Naumann 2013; PoSCoPP Research Group 2015; Miggelbrink and Meyer 2015). At the structural level, peripheralisation 
is linked to demographic shrinkage and ageing, to selective outmigration and a lack of in-migration, and to low income and low-quality occupation (Kreckel 2004; Bernt and Liebmann 2013; Kühn 2015). But behind the major flows of migration, there is a sum of active individuals who are reacting to core-periphery relations by moving - albeit in the same direction. Or, as Bernt and Liebmann $(2013,219-20)$ put it, by leaving the periphery, emigrants are "voting with their feet" to express the perceived lack of perspectives for the future in their hometowns. In this sense, from an actor-centred position, migration is a way for individuals to place themselves in a preferred living environment, depending on the needs and the possibilities that they and their families have.

But what causes someone to migrate? Recent scholarship shows that the decision is never simple, nor is it taken in a completely rational and optimising way. Instead, the decision is complex, taken because of multiple reasons, in relation to a person's social network. It is located within their individual biography, connected to all the macro-structures that have shaped their identity, as well as to personal life experiences, and entangled with their future aspirations (Boyle et al. 1998). This focus on agency shows that people engaged in migration are actively concerned with re-placing themselves in a preferred living environment, which they perceive as having a higher quality of life and greater chances for their and their families' well-being (ibid.). As this can mean different things to different people, mobility is shown to be an extremely cultural event (Fielding 1992) that can reveal personal values and attachments, and the entire world-view of those choosing to migrate. With the cultural character of migration transpiring, it becomes an example of behaviour, rather than a simple action. It becomes part of the person's identity, an "expression of people's sense of being at any one point in time” (Gutting 1996, 482).

With the composition and direction of mobility flows affecting coreperiphery relations at the structural level (see also Moldovan 2017), an actor-centred analysis can help identify how the interplay of core-periphery relations has triggered out-migration as a mechanism of coping with peripheralisation, while also suggesting potential strategies and policies that could combat peripheralisation. The following empirical material aims to achieve just that. Firstly, the main individual narratives and lines of reasoning behind emigrating are used to identify the most pressing structural deficits 
that peripheries are struggling with. Secondly, the narratives of public officials trying to increase local development reveal what strategies and policy tools peripheries are already employing and what is still lacking in order to decrease core-periphery inequalities.

\section{$3 \quad$ Taking Individual Mobility Decisions from the Periphery}

One of the drawbacks of the relational conceptualisation of peripheralisation is that it leaves unclear how to empirically identify peripheries (Bernt and Liebmann 2013; Kühn 2015). In order to avoid a physicalspatial bias, the first step taken in the selection of the twelve villages in which the fieldwork was conducted was based on quantitative data, to show a lower level of local development in terms of human, health, vital and material capital. ${ }^{1}$ In the second step, ten of the twelve villages were selected as a case study area for the present analysis (Map 2), based on whether the subjective perceptions of local political leaders

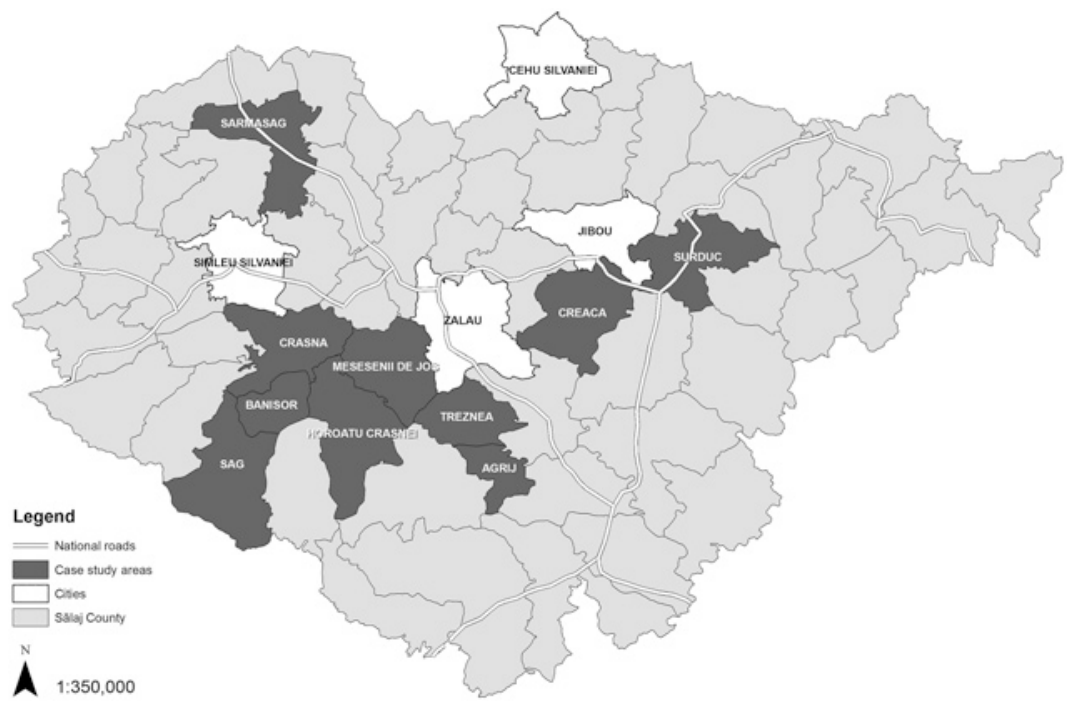

Map 2 Case study area: ten peripheral villages in Sălaj County. Source Prepared by the author 
and administrative workers fit the conceptual description of "peripheralisation". In the end, all ten villages (ranging in size from 1041 to 6710 inhabitants) share the following characteristics, albeit to various degrees: their population earn their main sources of income from low quality occupations (agriculture or low-skilled jobs), they lack physical infrastructure and facilities for higher education (only four of the villages have their own high school and vocational school, and the results of their students are quite poor), and they were described as struggling with population shrinkage and ageing, and with the out-migration of young adults. ${ }^{2}$ Outmigrants predominately move either to nearby cores to enrol in university courses and pursue highly-skilled occupations, or engage in temporary and circular migration abroad, if they occupy lower skilled professions.

To show how out-migration is employed as a strategy to cope with or to overcome peripheralisation and how cumulated individual decisions affect local development capacities, this chapter draws on a total of 28 semi-structured interviews with local public officials, and 134 structured interviews with locals from 10 peripheralised settlements of Sălaj County (Table 1). ${ }^{3}$ The first set of interviews was conducted with local

Table 1 The number of interviews conducted in the case study area

\begin{tabular}{lcc}
\hline Name of settlement & $\begin{array}{l}\text { Interviews with public } \\
\text { officials }^{\text {a }}\end{array}$ & $\begin{array}{l}\text { Interviews with local } \\
\text { inhabitants }\end{array}$ \\
\hline Agrij & 3 & 9 \\
Bănișor & 3 & 15 \\
Crasna & 3 & 15 \\
Creaca & 4 & 15 \\
Horoatu Crasnei & 2 & 12 \\
Meseșenii de Jos & 2 & 12 \\
Sărmășag & 3 & 15 \\
Sâg & 3 & 15 \\
Surduc & 3 & 15 \\
Treznea & 2 & 11 \\
Total & 28 & 134 \\
\hline
\end{tabular}

Source Prepared by the author

aln order to protect the anonymity of the public officials who agreed to the interviews, the present analysis lists the sources for relevant quotes by mentioning the respondent's occupation, but not the village of origin. Instead, each village has been assigned a random number from one to ten, in a non-alphabetical order 
political leaders and administrative workers, holding one of the following positions: mayor, deputy mayor, secretary of the mayor's office, ${ }^{4}$ social worker, official in charge of the agricultural registry, school secretary and accountant. These interviews sought to bring forth descriptions of the overall local socio-economic context, looking into the main issues that each village is struggling with as well as the strategies employed for local development. The second set of interviews was conducted with adult local inhabitants, who were presently employed or had been in the past. They were asked about their own occupational history, their personal experience with migration or commuting, and their future aspirations. In order to capture the complexity and the embeddedness of the decision to become mobile, these interviews also enquired about the status of other household members and how they all managed their everyday lives together, aiming to show how the interest of the entire family was considered when making occupational choices. In this way, the discussions were also marked by those who were absent, especially through stories of children who moved away, so that the interviews also highlighted aspects of long-term emigration.

\subsection{Local Strategies Employed by Individuals to Cope with Peripheralisation}

In the case study area, agriculture is the main economic activity of the inhabitants. Even if the interviews systematically excluded individuals living on subsistence agriculture (as this is not a form of employment and also not an occupation favouring territorial mobility), most respondents revealed that besides the various jobs they held, they cultivate patches of land and rear animals, in order to produce household products for their own consumption. Respondents who were employed in the settlement of residence mostly worked as labourers in one of the smaller shops or workshops, or held positions in the public sector. Salaries were often described as modest and the lack of jobs deemed more suitable in the home village was a commonly mentioned issue. Consequently, many locals have been looking for job offers elsewhere. Following the occupational history of the respondents, 
the interviews with locals reveal that they engage in four types of mobility in order to improve their situation: commuting, internal migration, international migration and temporary migration abroad. Choosing one of these mobilities is deeply connected to the actors' identity, aspirations, possibilities and attachments, and the choice reveals which structural disadvantages affect them the most. In this sense, each type of mobility represents a strategy to cope with the different effects of peripheralisation.

A first strategy employed is commuting to a town nearby. In fact, most respondents had themselves experienced commuting, either presently or in the past, or at least one of their family members had commuted for work. Mostly they or their family members commuted for low-skilled employment in industry or in services and trade. However, the interviews reveal a generational shift in the attitude towards commuting: while during the socialist period commuting to one of the large industrial sites was common practice, nowadays it is the middle aged or older adults who still commute. For them, commuting offers access to a wider labour market, while also allowing them to remain in the homes that they have built in the village. In their narratives, they often contrast living in the village, in a house with a small garden, to living in the city, in a flat. Moreover, living in an apartment would deprive them of the additional income they get from subsistence agriculture, but it would also take them away from the rural lifestyle, which they perceive to be calmer, healthier and safer than the urban one. Their attitude can be summed up by this respondent:

I cannot move to Zalău if I grew up in the village, I don't like blocks of flats. The kids can go, if they want to, but I can't. (interview, Male, aged 45, Bănişor, July 2017)

Younger generations, however, seem to have their preferences reversed and favour migration over commuting. Since they are not living in the villages anymore, their stories were told by the parents or siblings left behind. And the story of internal migration starts with the local educational infrastructure. All analysed settlements have their own public kindergarten and primary school (up to 8th grade), and four of 
them also have their own high school and vocational school. However, the local high schools are not very prestigious. Their students systematically achieve low results at the Bacalaureat ${ }^{5}$ and tend to start working as qualified labourers after graduation. For this reason, the number of students who have started to commute to nearby cities to attend high school is quite high, even from those four villages where a local option of secondary schooling is available. The high school students who commute are usually amongst the more dedicated scholars, so after graduation they tend to enrol in a university and move to Zalău, Oradea or Cluj-Napoca. Once there, in order to supplement their income, they start taking part-time or seasonal jobs, creating their own professional networks in the city. Very few return to live and work in the village after finishing their studies, as the jobs they could find in the villages would not suit their level of expertise. Even when some may want to return and start a business themselves, they find that they cannot recreate for themselves the opportunities that they have found in the city. A telling example is that of one respondent's son. He moved to Cluj-Napoca for studies and after he obtained his diploma, he tried to start a tailoring business in the village, but failed because he couldn't find employees:

I gave him the space, I gave him everything, he brought the latest machinery to open a tailoring shop. He barely found two people, and even those rather wanted to stay home. And after one and a half years, one of them moved to England. The other one got married and is on maternity leave, so she benefits now from having been employed. [...] So the boy moved to Cluj [...]. He does well for himself. (interview, Male, aged 57, Treznea, July 2017)

Another strategy employed by the locals, as a response to the low incomes available through employment in the peripheries, is international migration, for different periods of time. As the interviews revealed, some family members of the respondents had emigrated permanently, together with their spouses and children, and are only returning for summer holidays to visit their parents. Although absent, they are still investing in the village. Not only are they sending money back to their parents, but they are also renovating their childhood homes or 
building new houses, indicating that they would still like to return at some point in the future:

The children are abroad, they are working there, have kids on their own. They want to open a business and stand on their own two feet. They want to come here and open something in agriculture, but they keep saying that they'll stay one more year, then one more year. (interview, Male, aged 56, Bănișor, July 2017)

For those not willing to emigrate permanently, temporary or seasonal migration abroad represents the strategy for earning higher salaries. Usually they work in various European countries in agriculture, construction or caregiving. The specifics of their life stories differed considerably. Some were employed most of the year in the village or in a nearby city, but took unpaid leave to work for a couple of months abroad. Others combine episodes of seasonal work abroad with seasonal work locally and with social benefits. However, what came across in all of their stories was the desire to improve the quality of life for their family and the difficulty of having to leave their family behind for months at a time. In fact, the vast majority of the respondents do not want to go abroad for work, but the low salaries in the village or the region push them towards migration. For example, one respondent, who had been working seasonally in agriculture abroad and locally ever since his late teens, said that now he was looking for a job nearby, because he was about to become a father. But he was disappointed in the salaries he was being offered, considering them insufficient to cover basic expenses, especially since his wife has no income of her own:

It doesn't matter where I work, here, in Cluj, in Timişoara, in Spain, as long as we can get by as a family. But to be honest, if I could find a job here that is convenient with a salary of 2000-2200 RON, ${ }^{6}$ I wouldn't travel abroad anymore. I would stay here with my family. But for less money, I wouldn't stay, because we have to buy food, diapers, everything is expensive. (interview, Male, aged 24, Agrij, July 2017)

So while internal out-migrants tend to leave in order to access higher skilled employment in larger cities, in the case of international migrants 
it is not the low quality of the employment available locally that pushes them towards mobility, but rather the low income it results in, and the harsh working conditions it entails. One respondent, who has been working in Italy for 1-2 months each year since 2002 as a caregiver or as an assistant cook, was particularly vocal about how they wouldn't have been able to afford small renovation work on their house in the village or to help their oldest daughter through college in Oradea on just the salaries offered in Sălaj County:

In Zalău at Universal [a factory specialised in clothing manufacture] they are hiring every day. But they can look for employees all they want, if they won't offer salaries. They pay the minimum wage, around $1200 \mathrm{RON}$ I think it is. Then you pay $250 \mathrm{RON}$ for the commute and are left with under 1000 RON. You can't get by with that! [...] That's not even enough to manage on, let alone set something aside. [...] When we moved here, the house was in bad shape and all [the renovations] cost money. If I hadn't gone abroad, we wouldn't have managed anything. Unfortunately, that's where we have to go to be able to do something. [...] Here you work for 4-5 months, there you work for one month. ${ }^{7}$ And it's much more difficult here. (interview, Female, aged 49, Sâg, July 2017)

While the reasons to emigrate and the destinations of out-migration differ, the interviews revealed that there is one common trait that connects all types of migrants: they remain attached to their place of birth. In this sense, it isn't only the long-term international out-migrants who invest in local housing. Seasonal migrants too, invest large parts of their additional earnings in building or refurbishing their houses. And even internal out-migrants often choose to return from the cities to their home villages when they get close to retirement age, craving the quiet countryside life. One respondent, who lived most of her adult life in Zalău and just moved back two years ago, explained:

I always wanted a house in the countryside, because this is where I grew up. I like it here, I like gardening. My daughter visited us earlier today and I was so happy to give her vegetables from my garden. Now nothing could make me move away. (interview, Female, aged 48, Treznea, July 2017) 
The respondents don't mention it explicitly, but it is safe to assume that this favourable perception of the rural lifestyle results largely from improved living conditions in the village. These respondents have managed to substantially improve their housing conditions, by renovating houses, equipping them with bathrooms and appliances, purchasing new agricultural technologies, and modernising their households with the higher income earned elsewhere. And the villages have also been modernised with asphalted roads, running water, television, internet or other services. In fact, improving public services and the available physical infrastructure is one of the main strategies employed by local authorities to encourage commuting over out-migration, or even to attract new inhabitants, as the following subsection will explore in more detail.

\subsection{Development Strategies of Local Municipalities Against Peripheralisation}

Being responsible for devising local development strategies, public officials in peripheral villages are very aware of the challenges brought on by demographic changes. The selective out-migration of young adults, in response to existing peripheralisation, has consequences for the ways in which local administrations can operate. One of the direct consequences of having fewer young adults living in peripheries is that the number of children is also declining. In the villages analysed, kindergartens and schools are struggling with a decrease in the number of pupils and have had to reduce the number of units they operate and sometimes merge classrooms of students together, thus reducing the already poor educational infrastructure even more. When one unit closes, students from that area are usually transported by bus to a different school, which hikes education costs for the local administration:

The number of pupils is decreasing yearly, decreasing strongly... from 2008 until now it decreased around 40\%. There are fewer children, the birth rate is declining. [...] From 2008 until now four school units have closed because there were no pupils. (interview, School secretary, Village 7, July 2017) 
Education costs already put a strain on the local budget because some of the teachers are commuting from the cities nearby, and the villages cover their travel-related expenses:

Some of the employees at the school come from elsewhere. Monthly we pay for the teachers' commute 4000-4500 RON. ${ }^{8}$ They come from Zalău, from Șimleu [Silvaniei], from neighbouring settlements and have their main work quota here. There are also some locals employed at the schools. (interview, Secretary, Village 9, July 2017)

This stems from a more general difficulty in keeping more educated locals as permanent residents, because not only teachers, but also other employees from the public sector are often not locals. More generally, this issue showcases how peripheries depend on cores in order to maintain such essential facilities as schools, day care centres or doctors' offices, since they cannot provide the necessary specialised workforce themselves.

Another problem intensified by selective out-migration-and the implicit population shrinkage that it brings-is low public income. And not only do the peripheral villages collect small incomes from taxes, but they also lack the capacity to attract major economic investors, as large enterprises wouldn't be able to find the necessary work force locally:

Enterprises... it's difficult because with the ageing population there is no way an investor could find sufficient labour force. (interview, Mayor, Village 1, July 2017)

As a result, the villages analysed sourced most of their money from national or European funds. Such a dependence on external funds for maintaining or improving local infrastructure dictates local actions to a high degree, as the villages analysed seek to fulfil the necessary criteria that would make them eligible for whichever funding opportunity is being promoted at that time at the regional, national or European level. When asked about projects implemented in the recent past, public officials mentioned mainly infrastructure investments, including the paving 
of roads, refurbishing of community centres, building of day care centres and touristic information points, as these were the projects promoted through recent funding programmes. This is illustrative of the limited capacity of peripheries to react to actual local needs and to secure a better quality of life for their population. They even acknowledge that sometimes the projects they applied for weren't necessarily a priority, but that they just tried to access as many funds as possible and to make the best of a bad situation:

We had a project that was already approved for a sewage system, the money was already approved, but during the Boc government ${ }^{10}$ they withdrew the funding. [...] So we did what we could then, you know, the money is granted according to programmes. If there is a project for... people don't understand, "why did you refurbish this community centre, we don't need it». Well, it's not about need, that's how they issued funds, on refurbishing community centres. But some don't understand, «why didn't you use the money to implement...». You can't! When it's for paving, it's for paving, you can't move the money where you want. These are European funds, you can't spin it the way you want. So that's why we refurbished as much as we could, even schools, we transformed some of them in community centres. (interview, Deputy Mayor, Village 7, July 2017)

This quote showcases very well how the issue for peripheries is not always a lack of resources. Instead the problem lies in the way in which these resources are allocated, in a way that doesn't engage with local needs and potentials. Sometimes, public officials acknowledge that a certain project would not bring any benefits to their community and decide not to invest time and effort in it. For example, Village 2 refused to apply for European funds for a tourist information centre, even though they were easily accessible at that time, knowing that they don't receive many tourists. In these cases the interviewees were especially vocal about their frustration with the way funds were being allocated, and blamed the national administration for not giving them more support in developing local potential. In the case of Village 2, the mayor considered that their biggest potential was agriculture: 
They made a big mistake in both the previous and the current National Rural Development Programme, because they should have allocated a large part of the money to enable people to open farms. At least two farms with large crop surfaces, or at least two-three farms with animal husbandry should have been created in each village, with several employees. [...] Each farm would have employed 2-3-4 people to operate the necessary machinery. And the employees would have received a salary, paid taxes, and the entire standard of living could have been higher. [...] The Romanian state should have developed, should have made European funds easier to access [...]. The people here have tried, but they cannot meet the conditions for co-financing. It makes no sense how much money they spent on tourist centres here and we have no tourists. (interview, Mayor, Village 2, July 2017)

When asked about how they envisioned the future of their village, public officials said that they would like to see local potential being developed through encouraging larger scale and profit-oriented agriculture, or that they would like to attract investors and more inhabitants. The way to achieve this, they further elaborated, was through accessing more funds. More specifically, their development strategy for stimulating agricultural growth consisted in trying to help local inhabitants to access individual funds offered by the European Union, even if the results of this strategy have been mixed in the past, as locals with such ambitions have to meet strict requirements:

They [trainers on how to access European funds through APIA ${ }^{11}$ ] came and presented here for the people. But the people don't really dare. They face difficulties along the way... Others said too that the requirements are too high, for them to prepare you a project costs I don't know how much... I know people who prepared projects, but didn't follow through. They let it be. And they paid some money and were left without money. Or who wanted to have a pig farm and the poor guy bought the land and now he can't sell it because land was very expensive at that time... and he can't have the farm because he said there were some requirements to get the funds. (interview, Deputy Mayor, Village 7, July 2017)

Such a development strategy for attracting investors and more inhabitants also showcases a high dependency on external funding. As 
a result of selective out-migration and the implicit demographic shrinkage and brain drain, peripheral villages do not have sufficient (and sufficiently skilled) local work force to attract larger enterprises. Therefore, public officials plan to use available funds to invest in the admittedly lacking physical infrastructure and hope that this alone will strongly affect demographic and economic growth. Indeed, over the past years, all villages had seen major investments in basic infrastructure that was meant to improve local living conditions: paving main and secondary roads, trying to bring running water, sanitation system, internet lines, public lighting to as many corners of their village as possible. Some villages were more successful than others. In fact, the case study area suffers from a slow implementation of modern infrastructure, as is typical for peripheries (Bernt and Liebmann 2013), and only two of the villages are connected to gas pipelines, while three of them do not have access to running water. In the interviews, public officials stated their aim to provide all the necessities one could find in a city and hope that, with a better infrastructure, commuting could become more attractive to young adults who would otherwise choose out-migration. Also, in the case of villages closer to one of the cities, authorities plan to attract city dwellers and become suburbanised, thinking that a better connection to the urban core could result in local development. They are encouraged here by an increase in the number of migrants returning:

What I foresee for the future, and I encourage them to relocate here: our village is not far away from Zalău [...]. Many came from Zalău to settle down, building houses [...]. And that makes me happy, this resettlement from the city here, even if pensioners are coming. (interview, Deputy Mayor, Village 7, July 2017)

Additionally, they hope that the improved infrastructure could make the villages more attractive to investors as well, who could then be somehow persuaded to locate there and create jobs:

We hope the village will develop, but we will see if any foreigners come with foreign capital... it would be good... We have many young people who have moved away from the village, because there are no jobs. 
Around 100-200 have left the village permanently and I think that if foreign investments would come, they would stay here. (interview, Deputy Mayor, Village 8, July 2017)

This again highlights the dependency of the case study area to external funding, as well as the limited political power that peripheries have in relation to national or European decision makers. But at the same time, it also shows how peripheries strategise local development in relation to their dominant centre. Without explicitly referring to functional urban areas, the public officials appear to argue in favour of such sociospatial arrangements. It seems that they envision a stronger connection to a nearby urban core as a way to encourage commuting and discourage out-migration, with the implicit effects this would have on demographic shrinkage and ageing and on local budgets. Local leaders also expect that this strategy would generate additional economic spillovers, as investors would take better note of them, were there a better linkage between them and an economic centre. The fact that this strategy would also make them more dependent on that core does not seem to bother them.

\section{$4 \quad$ Re-thinking the Tools for Local Development in Peripheries: Conclusions}

The actor-centred approach that was employed in the present chapter focuses on how at times of polarisation, selective out-migration and local development influence each other. The decision of locals to leave peripheries because of existing structural deficits translates into a decrease of local tax income, active population, local capacity for innovation, and overall local capacities to secure a high quality of life for the inhabitants. This in turn motivates future cases of emigration and creates a vicious circle that reproduces peripherality. In the case study area analysed, locals had chosen to commute or to emigrate from peripheral villages in their pursuit for higher education, better skilled employment opportunities or higher income. Each specific strategy they employ in order to improve living conditions for themselves and their 
family (commuting, internal migration, international migration or temporary migration abroad) reveals different personal values and attachments, and highlights how actors are affected in different ways by the various effects of peripheralisation. But the migration trajectories also expose the different scales of core-periphery dependency. The choices of destination show how peripheral villages are affected not only by nearby cities or the county seat Zalău, but also by regional urban centres, such as Oradea and Cluj-Napoca. It also highlights the peripheral position that Romania as a country occupies at the European scale.

Not being able to compete with urban cores or international destinations in terms of educational and occupational opportunities, and available physical, social and cultural infrastructure, the peripheries analysed experience demographic shrinkage and ageing as a result of youth emigration. This affects their local budgets and their ability to maintain existing public facilities, making them increasingly dependent on external public funds, which are allocated through national or European programmes targeting specific investments, as determined by the issuing institution. However, these are not sufficient to bridge the increasing coreperiphery gap. Empirical analysis has revealed that while all villages in the case study area struggle with the effects of peripheralisation, they do so in slightly varying ways and to different intensities. As a consequence, each village has specific deficits that are more urgent to address, and also different local potentials that could be developed through targeted action. Judging by the narratives of public officials, the policy tools they are utilising at the moment do not enable them to address their most pressing issues in a systematic way, but rather push all villages towards similar strategies and solutions. In this context, a settlement can only hope that their specific issues will become the subject of the next line of funding. This is the reason the current chapter argues in favour of devising and effectively communicating policy tools that would strengthen the ability of local administrations to act autonomously, which would grant them more power in actively influencing how funds allocated for stimulating local development can be spent. Empirical findings have shown that more dialogue is needed between actors from peripheries and regional and national policymakers, in which the former should be given a more active role in shaping the policies that affect them. 
Acknowledgements I would like to thank the monograph editors as well as the anonymous reviewers for their helpful comments on earlier drafts of this chapter. I would also like to thank the entire team of researchers and students from the Faculty of Sociology at the Babeș-Bolyai University Cluj-Napoca for the fruitful collaboration in preparing and conducting empirical research in the Sălaj County.

\section{Notes}

1. For a more detailed view on the methodology employed to measure regional inequalities between the settlements of the North-West Region through statistical data, see Moldovan (2017).

2. One of the two villages excluded from this analysis was described by public officials as having experienced a recent socio-economic increase: the population was growing, larger companies were attracting commuters themselves, some agricultural entrepreneurs had made larger investments, and migration abroad was diminishing. The other excluded village did not experience such socio-economic development. Locals there had pronounced pride in the local agricultural tradition and a strong feeling of attachment to the village, which seems to keep villagers from emigrating or commuting in larger numbers.

3. The fieldwork was organised in collaboration with the Faculty of Sociology from the Babeș-Bolyai University in Cluj-Napoca. Data were collected by a team of six researchers (including the author), who spoke with political leaders and administrative workers, and sixteen undergraduate students, who completed their mandatory professional practice through this fieldwork by interviewing locals. All interviews were held in Romanian, relevant quotes have been translated into English.

4. The position of secretary in Romanian local government refers to an official who holds responsibility for the general management of the town hall. A secretary organises and directly manages the activities of the local administration according to written provisions laid out by the mayor.

5. The Bacalaureat is a national exam held in Romania after the 12th grade, after graduating from high school. 
6. At the time of the interviews (2017), 1 EUR was worth about 4.56 RON. So the amount mentioned, of 2000-2200 RON, is equivalent to 450-480 EUR, and represents about twice the minimum net wage, which at the time of the interview was set at 1065 RON.

7. Regarding the sums of money, the respondent is comparing how long it would take to earn about 1000 EUR: one month abroad, and 4-5 months in Sălaj. 1000 EUR seems to be the usual amount of money earned by temporary migrants, as this amount was mentioned by other respondents as well.

8. The amount mentioned, of $4000-4500 \mathrm{RON}$, is equivalent to 900 1000 EUR.

9. In fact, Sălaj County has the second smallest estimated operational budget for County Councils and County Residences, for the 2014-2023 Implementation period in the entire country (Cristea et al. 2017, 139).

10. Emil Boc was the prime minister of Romania during 2008-2012.

11. APIA stands for the Agency for Agricultural Payments and Interventions (in Romanian: Agenţia de Plăţi şi Intervenţie pentru Agricultură).

\section{Recommendations for Further Readings}

Bernt, Matthias, and Heike Liebmann, eds. 2013. Peripherisierung, Stigmatisierung, Abhängigkeit? Deutsche Mittelstädte und ihr Umgang mit Peripherisierungsprozessen. Wiesbaden: Springer VS.

Boyle, Paul, Keith Halfacree, and Vaughan Robinson. 1998. Exploring Contemporary Migration. Essex: Addison Wesley Longman.

Fischer-Tahir, Andrea, and Matthias Naumann. 2013. Peripheralization: The Making of Spatial Dependencies and Social Injustice. Wiesbaden: Springer VS.

Lang, Thilo, Sebastian Henn, Wladimir Sgibnev, and Kornelia Ehrlich, eds. 2015. Understanding Geographies of Polarization and Peripheralization: Perspectives from Central and Eastern Europe and Beyond. New Geographies of Europe. Basingstoke: Palgrave Macmillan.

Moldovan, Aura. 2017. Peripherialisation as a Result and Driving Force of Territorial Mobility in Post-Socialist Romania. European Spatial Research and Policy 24 (2): 39-57. https://doi.org/10.1515/ esrp-2017-0008. 


\section{References}

Benedek, József. 2015. "Spatial Differentiation and Core-Periphery Structures in Romania." Eastern Journal of European Studies 6 (1): 49-61.

Benedek, József, and Aura Moldovan. 2015. "Economic Convergence and Polarisation: Towards a Multi-dimensional Approach." Hungarian Geographical Bulletin 64 (3): 187-203.

Bernt, Matthias, and Heike Liebmann. 2013. "Zwischenbilanz: Ergebnisse und Schlussfolgerungen des Forschungsprojektes." In Peripherisierung, Stigmatisierung, Abhängigkeit? Deutsche Mittelstädte und ihr Umgang mit Peripherisierungsprozessen, edited by Matthias Bernt and Heike Liebmann, 218-31. Wiesbaden: Springer VS.

Boyle, Paul, Keith Halfacree, and Vaughan Robinson. 1998b. Exploring Contemporary Migration. Essex: Addison Wesley Longman.

Cristea, Marius, Codruţa Mare, Ciprian Moldovan, Andreea-Mirela China, Thomas Farole, Adina Vințan, Jane Park, Keith Patrick Garrett, and Marcel Ionescu-Heroiu. 2017. Magnet Cities: Migration and Commuting in Romania. Washington, DC: World Bank. http://documents.worldbank. org/curated/en/327451497949480572/pdf/1 16400-WP-P158178-PUBLIC-MagneticCities-Jun18-v4.pdf.

Fielding, Anthony. 1992. "Migration and Culture." In Migration Processes and Patterns. Volume I: Research Progress and Prospects, edited by Tony Champion and Anthony Fielding, 201-12. London: Belhaven Press.

Fischer-Tahir, Andrea, and Matthias Naumann. 2013. "Introduction: Peripheralization as the Social Production of Spatial Dependencies and Injustice." In Peripheralization: The Making of Spatial Dependencies and Social Injustice, edited by Andrea Fischer-Tahir and Matthias Naumann, 9-26. Wiesbaden: Springer VS.

Gottdiener, Mark, and Leslie Budd. 2005. Key Concepts in Urban Studies. London: Sage.

Gutting, Daniel. 1996. "Narrative Identity and Residential History." Area 28: 482-90.

Ionescu-Heroiu, Marcel, Sebastian Ioan Burduja, Dumitru Sandu, Stefan Cojocaru, Brian Blankespoor, Elena Iorga, Enrico Moretti, Ciprian Moldovan, Titus Man, Raularian Rus, and Roy van der Weide. 2013. Competitive Cities: Reshaping the Economic Geography of Romania. Romania Regional Development Program. Full Report. Washington, DC: World Bank. http://documents.worldbank.org/curated/en/664361468093270286/ pdf/843240v10Full00s0Box382123B00OUO070.pdf. 
Keim, Karl-Dieter. 2006. "Peripherisierung ländlicher Räume - Essay." Aus Politik und Zeitgeschichte 37: 3-7. http://www.bpb.de/apuz/29544/ peripherisierung-laendlicher-raeume-essay? $\mathrm{p}=$ all.

Kreckel, Reinhard. 2004. Politische Soziologie der Sozialen Ungleichheit, 2nd ed. Frankfurt: Campus.

Kühn, Manfred. 2015. "Peripheralization: Theoretical Concepts Explaining Socio-Spatial Inequalities." European Planning Studies 23 (2): 367-78. https://doi.org/10.1080/09654313.2013.862518.

Kühn, Manfred, and Sabine Weck. 2013. "Peripherisierung - ein Erklärungsansatz zur Entstehung von Peripherien.” In Peripherisierung, Stigmatisierung, Abhängigkeit? Deutsche Mittelstädte und ihr Umgang mit Peripherisierungsprozessen, edited by Matthias Bernt and Heike Liebmann, 24-46. Wiesbaden: Springer VS.

Kurkó, Ibolya. 2010. Disparităţi geodemografice şi economice din România în perioada de tranziție. Cluj-Napoca: Presa Universitară Clujeană.

Lang, Thilo. 2011. "Regional Development Issues in Central and Eastern Europe: Shifting Research Agendas from a Focus on Peripheries to Peripheralisation?" In Geography in Visegrad and Neighbour Countries, edited by Ágnes Erőss and Dávid Karácsonyi, 57-64. Budapest: E-Government Alapítvány.

Leibert, Tim. 2013. "The Peripheralization of Rural Areas in Post-Socialist Central Europe. A Case of Fragmenting Development? Lessons for Rural Hungary." In Peripheralization: The Making of Spatial Dependencies and Social Injustice, edited by Andrea Fischer-Tahir and Matthias Naumann, 101-20. Wiesbaden: Springer VS.

Leibert, Tim. 2015. "Abwanderung Jugendlicher aus postsozialistischen ländlichen Räumen.” Geographische Rundschau 67 (9): 34-41.

Massey, Douglas. 1990. "Social Structure, Household Strategies, and the Cumulative Causation of Migration.” Population Index 56 (1): 3-26.

Meyer, Frank, und Judith Miggelbrink. 2015. "Subjektivität und Kausalität in der Migration(sforschung) - Annäherungen an Rationalisierungen von Migrationsentscheidungen in schrumpfenden Regionen.” Raumforschung und Raumordnung 73 (1): 17-30.

Moldovan, Aura. 2017. "Peripherialisation as a Result and Driving Force of Territorial Mobility in Post-Socialist Romania." European Spatial Research and Policy 24 (2): 39-57. https://doi.org/10.1515/esrp-2017-0008.

Nagy, Erika, Judit Timár, Gábor Nagy, and Gábor Velkey. 2015. "The Everyday Practices of the Reproduction of Peripherality and Marginality in Hungary." 
In Understanding Geographies of Polarization and Peripheralization. Perspectives from Central and Eastern Europe and Beyond, edited by Thilo Lang, Sebastian Henn, Wladimir Sgibnev, and Kornelia Ehrlich, 135-55. New Geographies of Europe. Basingstoke: Palgrave Macmillan. PoSCoPP Research Group. 2015. "Understanding New Geographies of Central and Eastern Europe." In Understanding Geographies of Polarization and Peripheralization: Perspectives from Central and Eastern Europe and Beyond, edited by Thilo Lang, Sebastian Henn, Wladimir Sgibnev, and Kornelia Ehrlich, 1-21. New Geographies of Europe. Basingstoke: Palgrave Macmillan.

Pütz, Robert. 1999. "Ostmitteleuropa auf dem Weg in die EU.” Praxis Geographie 29 (9): 4-9.

Spoor, Max. 2013. "Multidimensional Social Exclusion and the 'Rural-Urban

Divide' in Eastern Europe and Central Asia." Sociologia Ruralis 53 (2): 13957. https://doi.org/10.1111/soru.12008.

Surd, Vasile, Ianos Kassai, and Laura Giurgiu. 2011. "Romania Disparities in Regional Development." Procedia Social and Behavioral Sciences 19: 21-30. https://doi.org/10.1016/j.sbspro.2011.05.102.

Török, Ibolya. 2014. "From Growth to Shrinkage: The Effects of Economic Change on the Migration Processes in Rural Romania." Landbauforschung 64 (3/4): 195-206. https://doi.org/10.3220/LBF_2014_195-206.

Warf, Barney. 2008. "From Surfaces to Networks." In The Spatial Turn: Interdisciplinary Perspectives, edited by Barney Warf and Santa Arias, 59-76. London: Routledge. 
Open Access This chapter is licensed under the terms of the Creative Commons Attribution 4.0 International License (http://creativecommons. org/licenses/by/4.0/), which permits use, sharing, adaptation, distribution and reproduction in any medium or format, as long as you give appropriate credit to the original author(s) and the source, provide a link to the Creative Commons license and indicate if changes were made.

The images or other third party material in this chapter are included in the chapter's Creative Commons license, unless indicated otherwise in a credit line to the material. If material is not included in the chapter's Creative Commons license and your intended use is not permitted by statutory regulation or exceeds the permitted use, you will need to obtain permission directly from the copyright holder. 